JURNAL ILMIAH ELEKTRONIKA DAN KOMPUTER, Vol.13, No.1, Juli 2020, pp. 103 - 115

p-ISSN : $1907-0012$ (print)

e-ISSN : 2714-5417 (online)

http://journal.stekom.ac.id/index.php/elkom

- page 103

\title{
SISTEM INFORMASI BERBASIS PEMROGRAMAN BERORIENTASI OBYEK UNTUK PENGADAAN BAHAN BAKU PADA CV. AINTZANE MANDIRI
}

\author{
Indra Ava Dianta ${ }^{1}$, Nuris Dwi Setiawan ${ }^{2}$, Tofani Wulandari ${ }^{3}$ \\ ${ }^{1}$ Teknik Komputer - Universitas STEKOM, indra@stekom.ac.id \\ ${ }^{2}$ Teknik Elektro - Universitas STEKOM, setyawan_dw@stekom.ac.id \\ ${ }^{3}$ Komputerisasi Akuntansi - Universitas STEKOM, faniwulan166@gmail.com \\ Jl. Majapahit 605, Semarang, telp/fax : 024-6717201-02
}

\begin{tabular}{l} 
ARTICLE INFO \\
\hline Article history: \\
Received 24 Juli 2020 \\
Received in revised form Juli 2020 \\
Accepted Juli 2020 \\
Available online Juli 2020
\end{tabular}

\begin{abstract}
CV Aintzane Mandiri is a company engaged in the field furniture. The Raw Material Manager at CV Aintzane is not yet optimal. Purchase Raw materials need to be considered because they will affect the maturity raw material needs and affect the production process.

The information system for the supply of raw materials is needed by the company determination of expenditure, input of raw materials, and can minimize supply of raw materials for optimal use throughout the process production.

Designing and building a procurement information system using raw materials Material Requirement Planning (MRP) method with programming language Microsoft Visual Basic 6.0, WAMP as server and MySQL as database. The results obtained from this information system can be obtained planning raw material requirements and production optimally and accordingly with company expectations.

Keywords : Materials Requirement Planning, Computerized Accounting, Wamp, MySql
\end{abstract}

\section{Pendahuluan}

Pengadaan bahan baku merupakan rencana penting dalam pembuatan keputusan strategis perusahaan, khususnya pada CV. Aintzane Mandiri. Perusahaan dapat menentukan kapan bahan baku harus disediakan, berapa jumlah bahan baku yang dipesan dan berapa jumlah bahan baku yang dibutuhkan oleh perusahaan dengan adanya pengadaan bahan baku. CV Aintzane Mandiri beralamat Dk. Tegalrejo, Ds. Tegalsari, Kec. Karanggede berdiri sejak tahun 2012, perusahaan ini bergerak dalam bidang mebel dan memproduksi barang jadi mebel sesuai permintaan konsumen. CV Aintzane Mandiri memproduksi barang berupa kursi, meja, almari, pintu, jendela, papan tulis, dan lainnya. Proses produksinya menggunakan bahan baku kayu jati yang akan diolah menjadi suatu produk. Kekurangan dan kelebihan menyediakan bahan baku dapat menjadi penyebab terjadinya penundaan dalam memproduksi suatu produk, sebaliknya kelebihan bahan baku dapat menyebabkan gudang menjadi penuh, apalagi jika bahan baku tersebut mengalami keterlambatan, maka berpengaruh pada usia bahan baku. Metode Material Requirement Planning (MRP) terdapat teknik lot sizing yaitu perhitungan yang digunakan untuk menentukan jumlah order suatu material sehingga biaya inventori dapat diminimumkan. Teknik lot sizing yang digunakan adalah hasil evaluasi dari beberapa teknik lot sizing 
yaitu lot for lot dan economic order quantity. Hasil evaluasi diperoleh berdasarkan total biaya persediaan bahan baku yang paling ekonomis.

\section{Perumusan Masalah}

1. Proses Pengadaan Bahan Baku menggunakan Metode Material Requirement Planning (MRP)

2. Hasil evaluasi Material Requirement Planning (MRP) menggunakan metode lot for lot dan metode economic order quantity, dapat memberikan informasi tentang jumlah kebutuhan bahan baku dalam proses produksi.

\section{Landasan Teori}

\section{a. Metode Material Requirement Planning (MRP)}

Metode MRP merupakan metode perencanaan dan pengendalian pesanan dan inventori untuk item-item dependent demand. Item-item yang termasuk dependent demand adalah bahan baku. MRP digunakan untuk mendukung jadwal produksi induk dan kapan kebutuhan material tersebut dijadwalkan (Handoko, 1991).

1. Struktur Sistem Material Requirement Planning Menurut (Handoko, 1991) terdiri atas komponen input, proses, dan output sebagai berikut

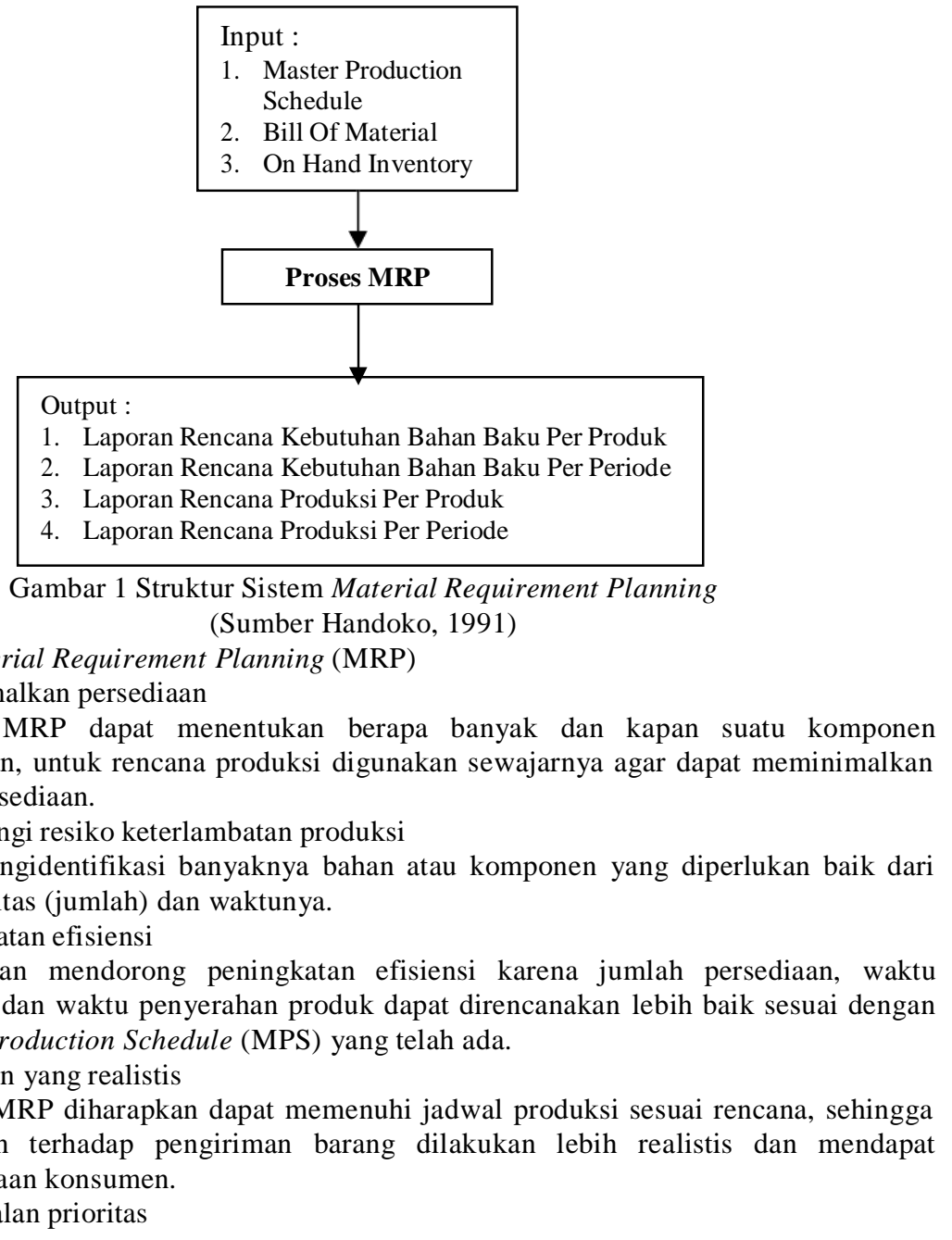

JURNAL ILMIAH ELEKTRONIKA DAN KOMPUTER Vol. 13, No. 1, Juli $2020: 78-86$ 
Peran MRP adalah menetapkan prioritas pemesanan secara valid, dan secara tepat dapat memberikan informasi analisis bila terjadi perubahan prioritas yang mengakibatkan penundaan, penjadwalan kembali ataupun pembatalan order.

3. Langkah-langkah dasar proses pengolahan MRP

a. Proses Netting

Merupakan proses perhitungan untuk menetapkan jumlah kebutuhan bersih yang besarnya merupakan selisih antara kebutuhan kotor dengan keadaan persediaan. Masukan yang diperlukan dalam proses perhitungan kebutuhan bersih ini adalah :

1. Kebutuhan kotor setiap periode

2. Persediaan yang ada ditangan

3. Rencana penerimaan pada periode mendatang.

b. Proses Lotting

Merupakan proses untuk menentukan besarnya pesanan setiap item berdasarkan kebutuhan bersih yang dihasilkan dari proses netting.

c. Proses Offsetting

Proses ini ditunjukan untuk menentukan saat yang tepat untuk melakukan perencanaan pemesanan dalam upaya memenuhi tingkat kebutuhan bersih.

d. Proses Exploding

Proses ini untuk menghitung kebutuhan item yang mempunyai level bawah. Data BOM sangat mempunyai peranan, karena atas dasar BOM inilah proses exploding akan berjalan.

4. Teknik Lot Sizing Dalam MRP

Ukuran jumlah barang yang dipesan (lot size) akan berhubungan dengan biaya pemesanan ( setup cost) dan biaya penyimpanan (holding cost) barang, semakin rendah ukuran lot, berarti semakin sering melakukan pemesanan barang akan menurunkan biaya penyimpanan. Sebaliknya semakin tinggi ukuran lot akan mengurangi frekuensi pemesanan, berarti mengurangi biaya pemesanan akan tetapi meningkatkan biaya penyimpanan. Maka dari itu perlu dicari ukuran lot yang tepat agar dapat meminimalkan total biaya persediaan. Adapun teknik-teknik lot menurut (Handoko, 1991) adalah sebagai berikut :

a. Lot For Lot (LFL)

Metode LFL dikenal sebagai metode persediaan minimal berdasarkan ide penyediaan persediaan sesuai dengan yang diperlukan saja, jumlah persediaan diusahakan seminimal mungkin. Metode ini beresiko tinggi, yaitu apabila terjadi keterlambatan dalam pengiriman barang, maka akan mengakibatkan terhentinya produksi.

b. Economic Order Quantity (EOQ)

Metode ini digunakan untuk permintaan yang tidak seragam dalam beberapa periode. Rata-rata permintaan dipergunakan untuk mendapatkan rata-rata jumlah bahan setiap kali pemesanan, rata-rata permintaan beberapa periode dijumlahkan selanjutnya dibagi dengan jumlah periode yang ada dan hasilnya dibulatkan kedalam angka integer. Angka terakhir yang menunjukkan jumlah ekonomis dalam setiap kali pemesanan.

Rumus EOQ :

$$
\begin{aligned}
& \mathrm{EOQ}=\sqrt{\frac{2 S D}{H}} \\
& \text { Keterangan : } \\
& \mathrm{D} \quad=\text { Penggunaan atau permintaan per periode waktu } \\
& \mathrm{S} \quad=\text { Biaya pemesanan per pesanan } \\
& \mathrm{H} \quad=\text { Biaya penyimpanan per unit pertahun }
\end{aligned}
$$

\section{b. Metode $\mathbf{R} \mathbf{n} \mathbf{D}$}

Menurut Borg and Gall (1983), educational research and development is a process used to develop and validate educational product, artinya bahwa penelitian pengembangan pendidikan (R\&D) adalah sebuah proses yang digunakan untuk mengembangkan dan memvalidasi produk pendidikan. Hasil dari penelitian ini tidak hanya untuk pengembangan sebuah produk yang sudah ada tetapi juga untuk menemukan pengetahuan dan juga jawaban atas permasalahan yang dimaksud.

Adapun bagan tahapan model pengembangan seperti ditunjukkan pada gambar berikut. 
Secara ringkas langkah-langkah penelitian R\&D menurut Borg and Gall diuraikan sebagai berikut.

1. Research and Information collecting, termasuk dalam langkah ini antara lain studi literature yang berkaitan dengan permasalahan yang dikaji dan persiapan untuk merumuskan kerangka kerja penelitian.

2. Planning (Perencanaan), termasuk dalam langkah ini merumuskan kecakapan dan keahlian yang berkaitan dengan permasalahan, menentukan tujuan yang akan dicapai pada setiap tahapan, dan jika mungkin/ diperlukan melaksanakan studi kelayakan secara terbatas, memikirkan produk apa yang kan dihasilkan.

3. Develop and preliminary form of product, yaitu mengembangkan bentuk permulaan dari produk yang akan dihasilkan.

4. Preliminary field testing (uji coba lapangan awal), yaitu melakukan ujicoba lapangan awal dalam skala terbatas dengan melibatkan subjek secukupnya.

5. Main Product Revison (Revisi hasil Uji coba), yaitu melakukan perbaikan terhadap produk awal yang dihasilkan berdasarkan hasil uji coba awal.

6. Main field testing (Uji lapangan produk utama), uji coba utama melibatkan stake holder. Disini dapat diuji coba output running program dengan mendapat pengesahan dari pihak ruang lingkup penelitian.

7. Operational product revision (Revisi produk), yaitu melakukan perbaikan/ penyempurnaan terhadap hasil uji coba lebih luas, sehingga produk yang dikembangkan sudah merupakan desain model operasional yang sudah siap validasi.

8. Operational field testing (uji coba lapangan skala luas/uji kelayakan), yaitu langkah uji validasi terhadap model operasional yang telah dihasilkan.

9. Final product revision (revisi produk final), yaitu melakukan perbaikan akhir terhadap model yang dikembangkan guna menghasilkan produk akhir(final).

10. Dissemination and implementation (Desiminasi danimplementasi), yaitu langkah penyebarluasan produk/model yangdikembangkan kepada khalayak/masyarakat luas.

\section{c. Wamp Server}

Menurut Enterprise (2016) mengatakan bahwa Wamp server merupakan singkatan dari "Windows, Apache, MySQL, dan PHP". Server development ini menyediakan pengaturan lengkap yang diperlukan untuk membangun sebuah halaman web yang dinamis.

\section{d. $\mathrm{MySQL}$}

MySQL database server adalah RDBMS (Rasional Database Management System) yang dapat menangani data yang bervolume besar.Meskipun begitu, tidak menuntut resource yang besar. MySQL adalah database yang paling popular diantara database-database yang lain. MySQL adalah program database yang mampu mengirim dan menerima data dengan sangat cepat dan multi user (Wahana Komputer, 2010).

\section{e. PHPMyAdmin}

Menurut Rahman (2013) menerangkan bahwa PHPMyadmin adalah suatu software berbasis pemrograman PHP yang dipergunakan sebagai administrator MySQL melalui browser (web) yang digunakan untuk management database.PHPMyadmin mendukung berbagai aktivitas MySQL seperti pengelolaan data, tabel, relasi antar tabel dan lain sebagainya.

Pada dasarnya penggunaan data pada MySQL dilakukan dengan mengetikkan perintah berupa kode-kode tertentu yang sesuai untuk tujuan tertentu, tetapi hal ini sangat menyulitkan karena penggunaanya harus mengingat setiap baris perintah agar pemrograman dapat berjalan dengan baik.

\section{Metodologi}

Metodologi penelitian adalah metode yang akan digunakan dalam melakukan sebuah penelitian. Dalam penelitian ini menggunakan metode RND, yang terdiri dari 6 tahapan, yaitu : Penelitian (Research and information collecting), Perencanaan (Planning), Pengembangan produk (Development preminary form of product), Uji coba tahap awal(Preliminary field testing), Revisi produk(Main product revision), Uji coba lapangan (Main field testing).

JURNAL ILMIAH ELEKTRONIKA DAN KOMPUTER Vol. 13, No. 1, Juli $2020: 78-86$ 


\subsection{Desain Penelitian}

Metode penelitian pada skripsi ini dilakukan dengan pendekatan model penelitian dan pengembangan ( R \& D) yang dapat diuraikan sebagai berikut: Model pengembangan diperlukan sebagai dasar pengembangan produk yang mengacu pada model Research and Development (R\&D) dari Borg and Gall. Model R\&D merupakan model rancangan pengembangan desain yang bertujuanuntuk mengembangkan dan menvalidasi produk. Pemilihan model Borg and Gall berdasarkan pertimbangan pada model pengembangan yang sudah tersusun dan terprogram dengan langkah-langkah persiapan dan perencanaan yang teliti, pada penelitian skripsi ini mengadopsi 6 tahapan dari 10 tahapan model penelitian pengembangan R\&D sebagai berikut:

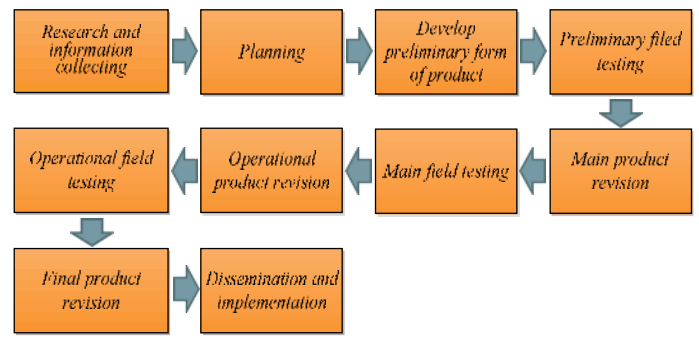

Gambar 3.1 Langkah-langkahpenggunaan Metode R and D (Sumber: Borg and Gall 1983)

\section{Research and information collecting (Penelitian dan pengumpulan informasi)}

a. Melakukan wawancara dengan pegawai dan pimpinan pada CV. Aintzane Mandiri Karanggede Boyolali.

b. Penulis melakukan observasi berkaitan sistem kerja yang digunakan pada saat ini, yaitu mencatat alur pengadaan bahan baku pada CV. Aintzane Mandiri Karanggede Boyolali..

c. Penulis juga melakukan studi literatur untuk mendapatkan teori-teori yang menunjang untuk sistem yang akan dikembangkan termasuk melakukan kajian penelitian yang relevan melalui referensi, buku teks, jurnal ilmiah di Perpustakaan dan sumber-sumber di internet.

d. Penulis menyusun kerangka pemikiran untuk memberikan solusi atas masalah yang ada ditempat penelitian melalui tahapan-tahapan penelitian dan pengembangan R\&D.

\section{Planning (Perencanaan)}

Pada tahap ini penulis membuat perencanaan tentang tujuan sistem yang akan dicapai pada setiap tahapan, membuat spesifikasi produk yang akan dikembangkan dan membuat jadwal kegiatan penelitian dari awal sampai selesai.

\section{Develop preliminary form of product (Membuat desain sistem)}

Pada tahap ini penulis membuat desain sistem informasi termasuk didalamnya: Desain arsitektural sistem, desainFlowchart atauFlow of Document (FOD), desain Data Flow Diagram (DFD), desain basis data, normalisasi tabel, Entity Relation Diagram (ERD), user Interface yang berupa forminput, proses dan output.

\section{Preliminary field testing (Validasi Desain)}

Melakukan uji validasi desain sistem oleh pakar yang diwakili oleh dosen yang kompeten di bidang sistem informasi. Uji validasi desain dilakukan dengan menggunakan instrumen penelitian berupa angket (form validasi desain dengan melibatkan pakar).

\section{Main product revision (Revisi Desain)}

Melakukan perbaikan terhadap desain sistem informasi yang telah diuji oleh pakar, jika masih ditemukan kekurangan akan diperbaiki sesuai petunjuk dari pakar. Perbaikan desain bisa dilakukan lebih dari satu kali sampai desain sistem dinyatakan valid oleh pakar. 
6. Main field testing (Uji coba produk di lapangan oleh calon User)

Setelah desain sistem dinyatakan valid oleh pakar, kemudian dibuat source code menjadi running program yaitu prototypeproduk aplikasi. Produk aplikasi ini akan diuji di lapangan oleh calon user yaitu: kepala mekanik, mekanik dan pimpinan sebagai calon pengguna sistem, dan konsumen memberikan penilaian apakah prototype sudah sesuai dan memenuhi kebutuhan pengguna atau belum? Apabila prototype sistem belum baik atau ada masukan koreksi dari calon pengguna, maka prototypeakan dilakukan perbaikan sesuai petunjuk pengguna. Pengujian lapangan oleh calon pengguna menggunakan instrumen penelitian berupa angket yaitu lembar pengujian yang melibatkan user.Hasil akhir pengujian harus dinyatakan baik oleh calon pengguna.

\subsection{Context Diagram}

Project Name: Sistem Informasi Pengadaan BB
Project Path: d:Iskripsildfdnew\} $\\{\text { Chart File: dfd00001.dfd }} \\{\text { Chart Name: Context Diagram }} \\{\text { Created On: Oct-06-2018 }} \\{\text { Created By: Tofani Wulandari }} \\{\text { Modified On: Oct-06-2018 }} \\{\text { Modified By: Tofani Wulandari }} \end{array}$

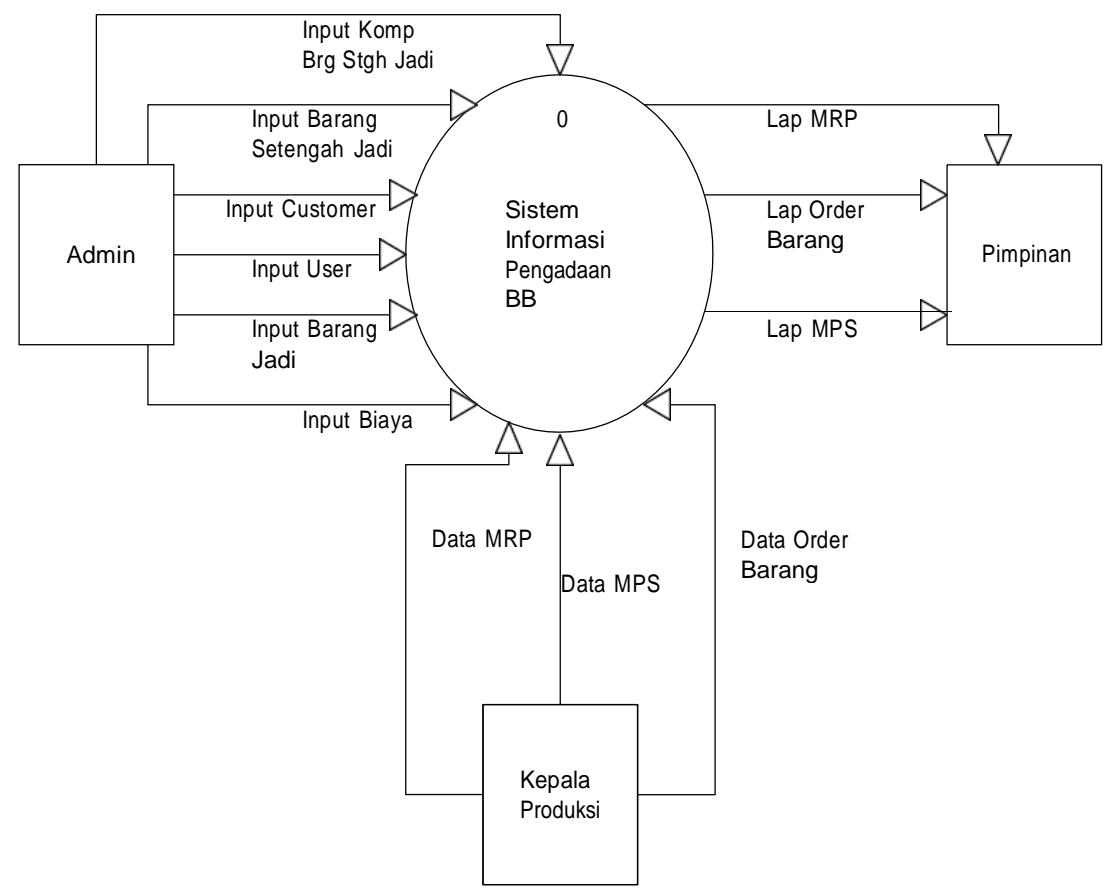

Gambar 3.2 Context Diagram

JURNAL ILMIAH ELEKTRONIKA DAN KOMPUTER Vol. 13, No. 1, Juli $2020: 78-86$ 
3.3 ERD (Entity Relationship Diagram)

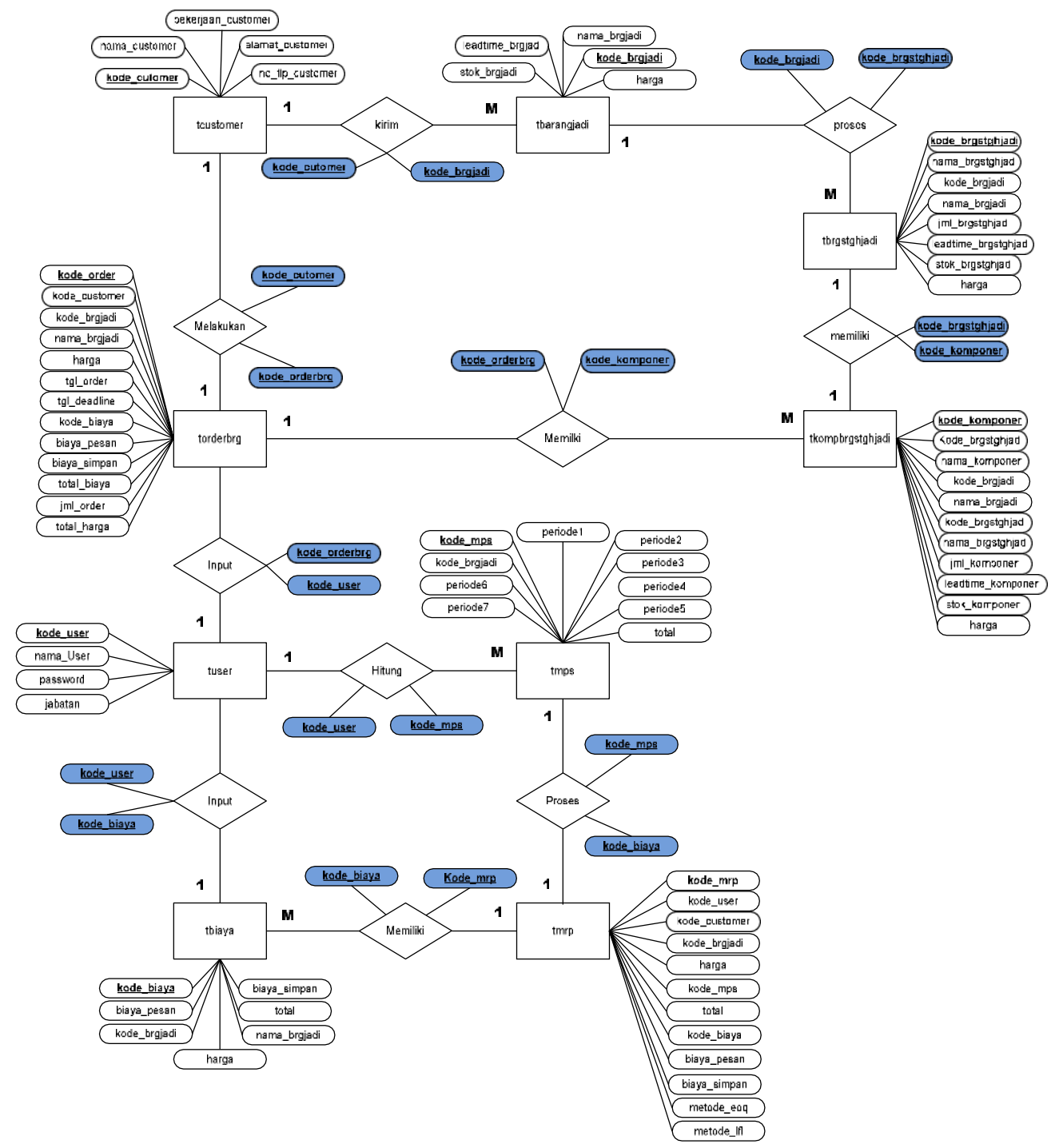

Gambar 3.3 ERD (Entity Relationship Diagram)

4. Hasil dan Pembahasan

a. Halaman Login

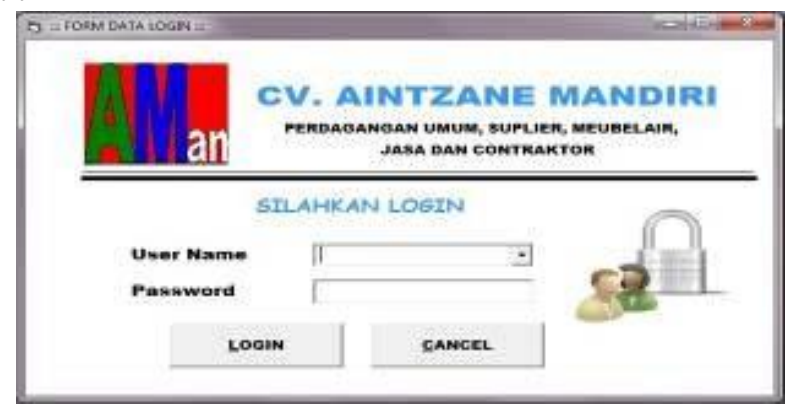

Gambar 4.1 Halaman Login 
Tampilan login digunakan untuk masuk sebagai user/ pengguna.

b. Halaman Home

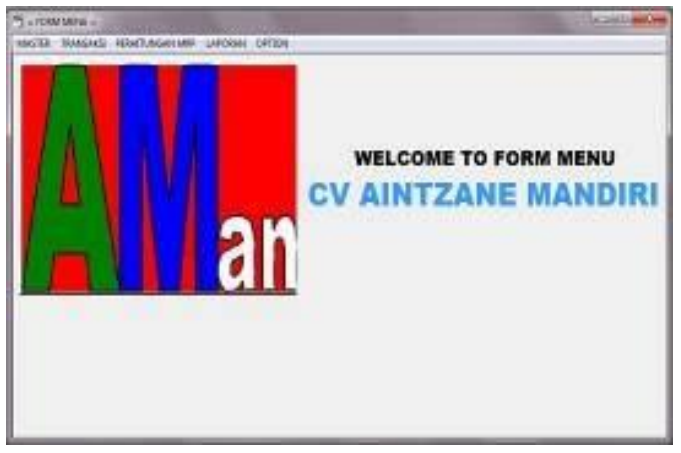

Gambar 4.2 Halaman Home

Home adalah tampilan awal program dijalankan setelah berhasil login.

c. Halaman Data User

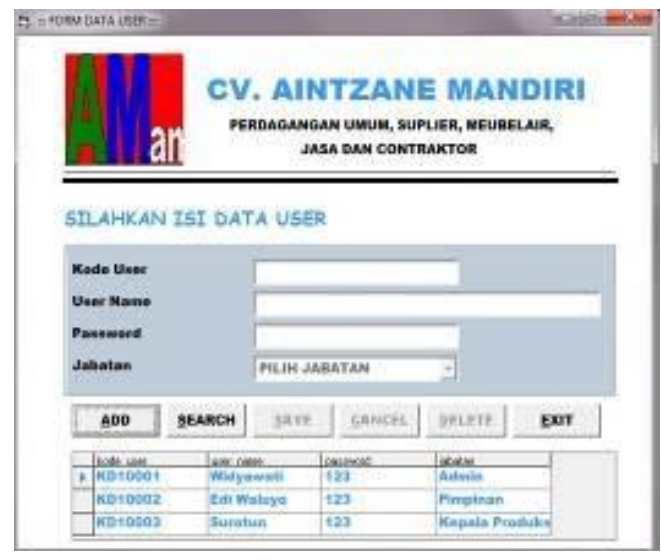

Gambar 4.3 Halaman Data User

d. Halaman Master Customer

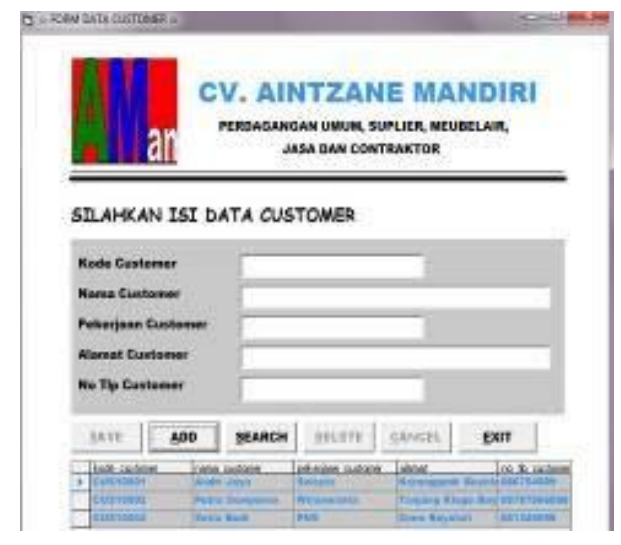

Gambar 4.4 Halaman Master Customer

JURNAL ILMIAH ELEKTRONIKA DAN KOMPUTER Vol. 13, No. 1, Juli $2020: 78-86$ 
e. Halaman Barang Jadi

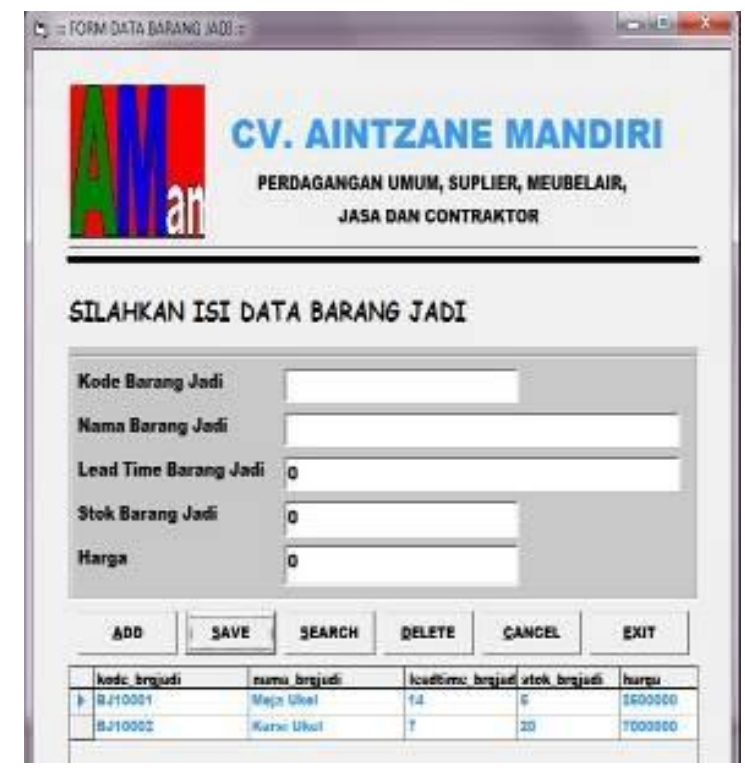

Gambar 4.5 Halaman Barang Jadi

f. Halaman Barang Setengah Jadi

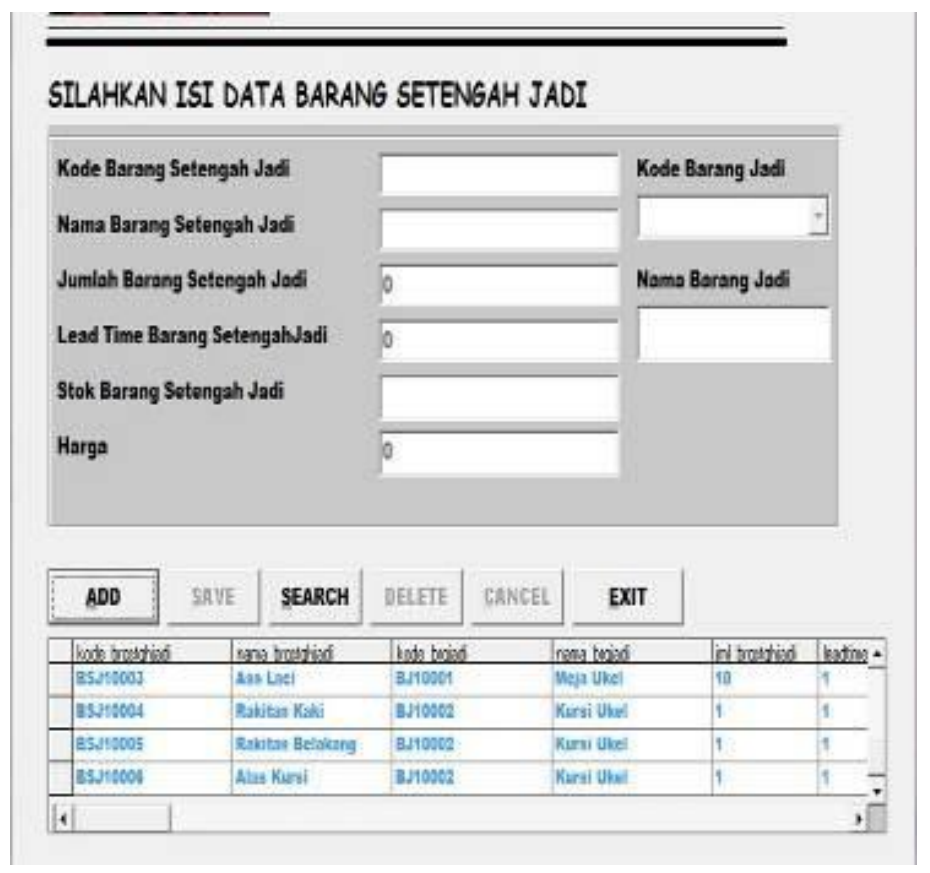

Gambar 4.6 Halaman Barang Setengah Jadi 
g. Halaman Komponen Barang Setengah Jadi

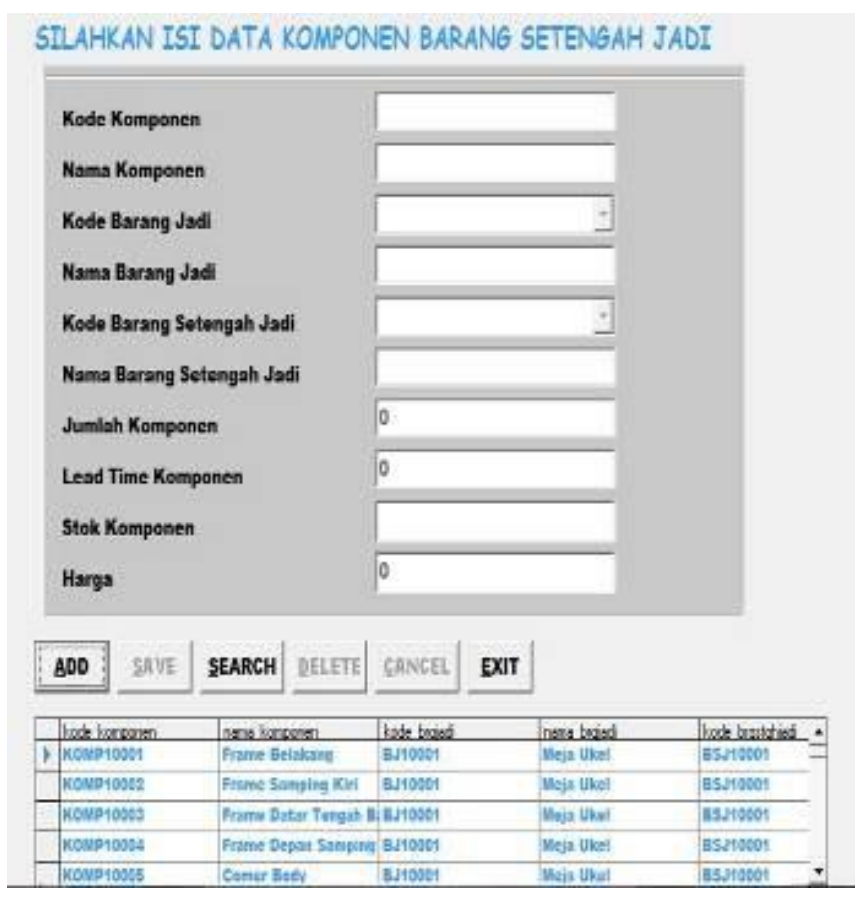

Gambar 4.7 Halaman Komponen Barang Setengah Jadi

h. Halaman Biaya

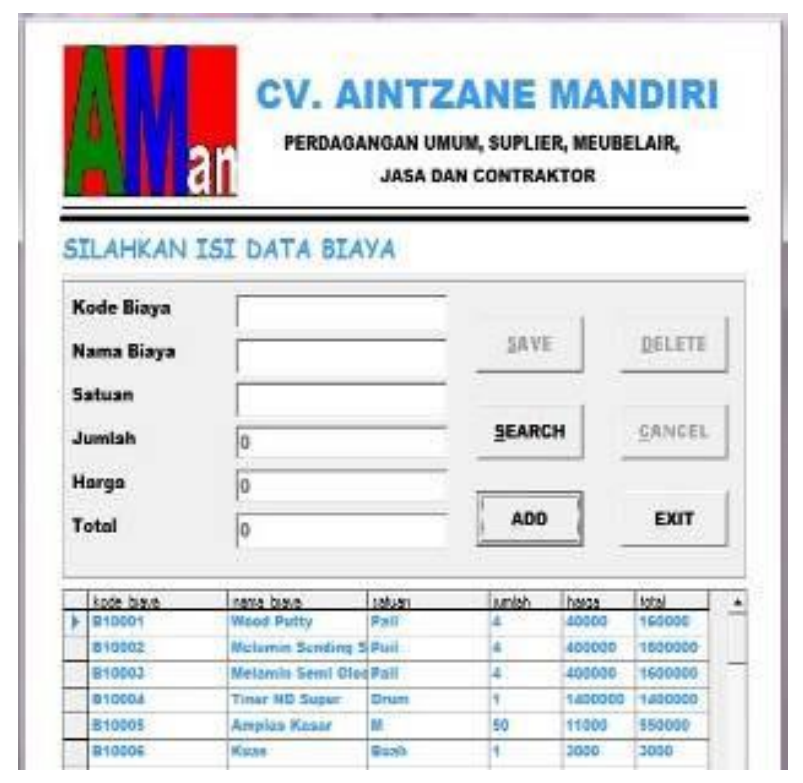

Gambar 4.8 Halaman Biaya

JURNAL ILMIAH ELEKTRONIKA DAN KOMPUTER Vol. 13, No. 1, Juli 2020 : 78 - 86 
i. Halaman Pegawai

j. Halaman Bahan Baku

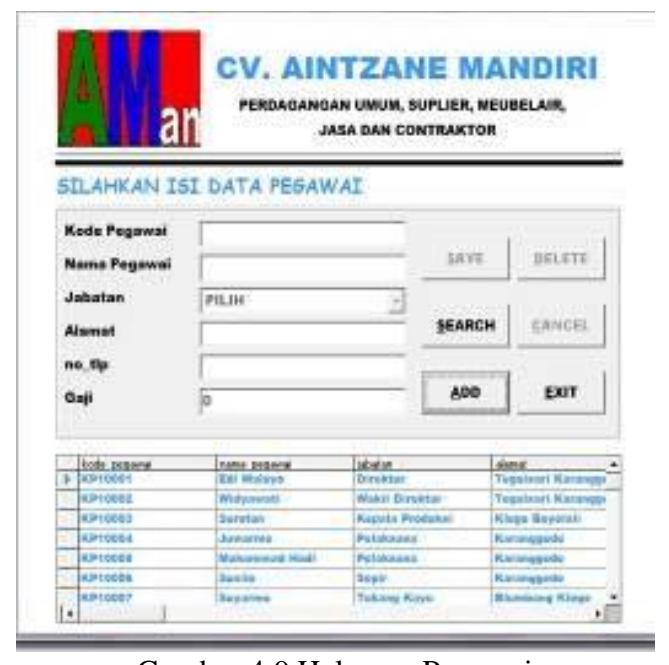

Gambar 4.9 Halaman Pegawai

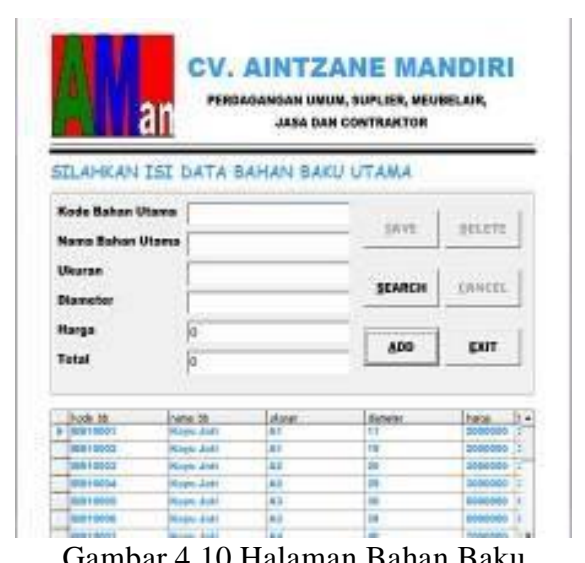

k. Halaman Order Barang

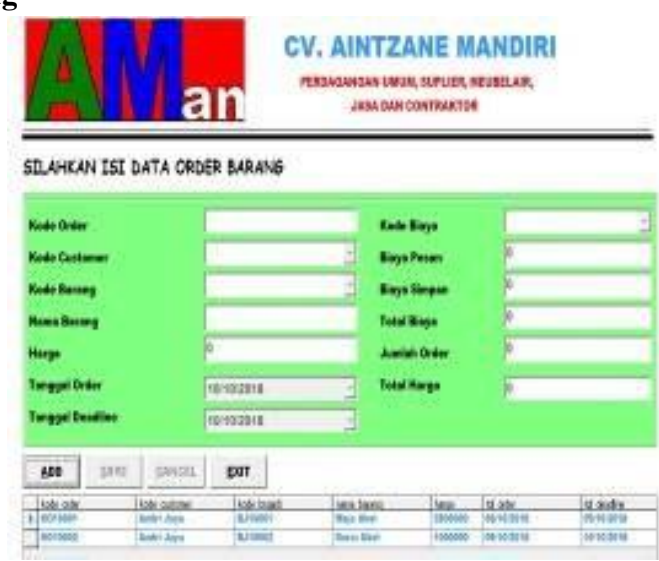

Gambar 4.11 Halaman Order Barang 


\section{l. Halaman MPS}

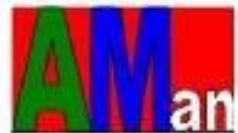

CV. AINTZANE MANDIRI

PESRQGNOAN UAUR, SUPLER, NEUBELAIR. JASh dAN COKTRKKTOR

SILAHKAN ISI DATA MPS
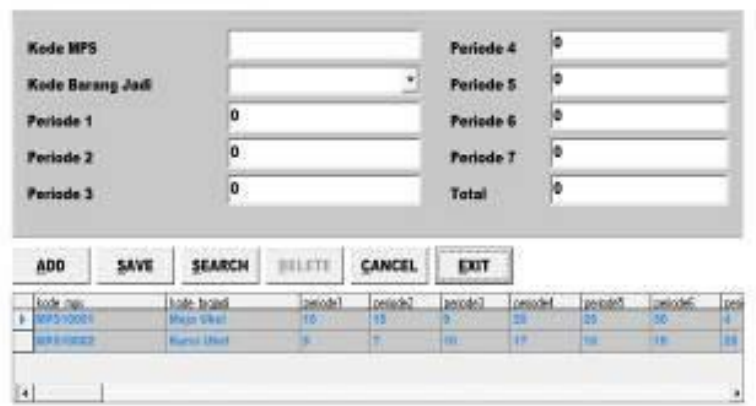

Gambar 4.12 Halaman MPS

\section{m. Halaman MRP}

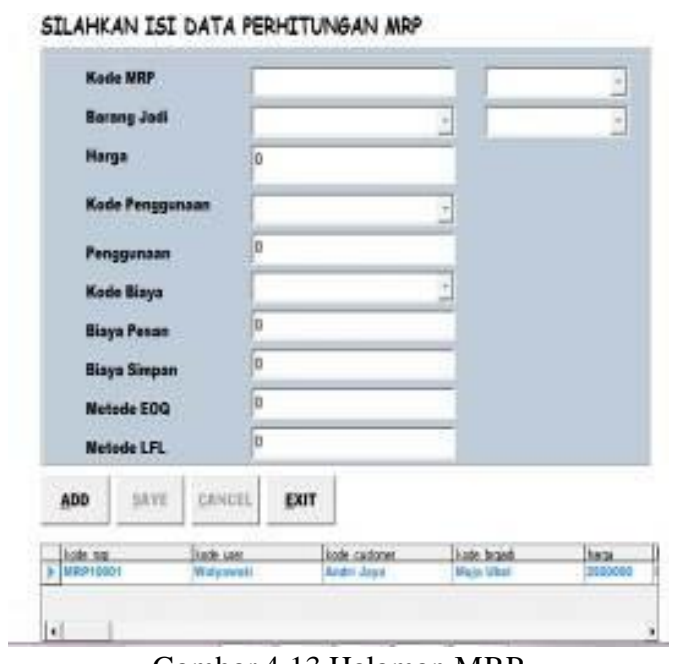

Gambar 4.13 Halaman MRP

\section{Kesimpulan}

Sistem informasi pengadaan bahan baku pada cv. Aintzane mandiri dengan menerapkan metode material requirement planning ( $\mathrm{mrp}$ ) dilakukan dengan membuat rancangan sistem baru yang telah melalui pengujian desain oleh pakar dan juga ujicoba prototype produk oleh user maka protoype sistem yang telah dikembangkan dinyatakan memenuhi syarat tujuan yang diharapkan, sehingga dapat ditarik kesimpulan sebagai berikut:

a. Aplikasi sistem informasi pengadaan bahan baku pada cv. Aintzane mandiri dengan menerapkan metode material requirement planning (mrp)dapat meminimalkan pengeluaran biaya bahan baku.

b. Aplikasi sistem informasi pengadaan bahan baku pada cv. Aintzane mandiri dengan menerapkan metode material requirement planning (mrp) lebih baik menggunakan metode Lot Sizing.

JURNAL ILMIAH ELEKTRONIKA DAN KOMPUTER Vol. 13, No. 1, Juli 2020 : 78-86 


\section{Daftar Pustaka}

Aryanto, 2016; “Pengolahan Database MySQL”, Yogyakarta: Deepublish.

Borg, W.R., \& Gall, M.D., 1983; "Education Research: An introduction", Fifth Edition. New York: Longman.

Enggar,dkk. 2017; “Analisis Pengendalian Persediaan Bahan Baku Guna Meminimalkan Biaya Persediaan Pada Dunkin Donuts Manado", Fakultas Ekonomi : Jurusan Manajemen.Universitas Sam Ratulangi Manado.Volume 5-ISSN:2303-1174

Enterprise, J. 2016, Belajar Java, Database dan NetBeans dari Nol, PT. Elex Media Komputindo, Jakarta. Fachrurrozi, dkk; "Lot Sizing Material Requirement Planning Pada Produk Tipe Wall Mounting Di Industri Box Panel”, Fakultas Teknik:Teknik Industri Universitas Mercu Buana Jakarta.Volume X No.3, 279-293.

Fauzi, Rizki Ahmad, 2017; "Sistem Informasi Akuntansi (Berbasis Akuntansi”) .Ed. 1,Cet.1Yogyakarta:Deepublish xi,124 hlm;Uk:14x20 cm.ISBN:978-602-453-138-6.

Handoko, T. Hani, 1991; "Manajemen Personalia dan Sumberdaya Manusia”, Yogyakarta: BPFEYOGYAKARTA

Hutahaean, Jeperson, .2014; “Konsep Sistem Informasi”, Ed. 1,Cet. 1 -Yogyakarta: Deepublish.xi, 116 hlm; $14 \times 20 \mathrm{~cm}$. ISBN:978-602-280-672-1.

Jayana, Ketut. 2014; “Analisis Perencanaan Kebutuhan Bahan Baku Dalam Pembuatan Meubel Menggunakan Metode Material Requirement Planning”, Fakultas Ekonomi dan Bisnis:Universitas Pendidikan Ganesha. Volume 4.

Kale, F.Daniel, dkk. 2016; "Rancang Bangun Sistem Informasi Perncanaan Bahan Baku dan Produksi Menggunakan Metode Material Requirement Planning”, Fakultas Teknologi dan Informatika:Institut Bisnis dan Informatika STIKOM Surabaya.

Hendrayudi, 2009; "VB 2008 untuk Berbagai Keperluan Programming”, Jakarta: PT. Elex Media Komputindo.

Komputer, Wahana, 2010; “MySQL Database Server”, Jakarta: Mediakita.

Mustakini, Jogiyanto Hartono, 2009; "Sistem Teknlogi Informasi”, Yogyakarta: Andi.

Prasetio, Adhi, 2015; "Pintar WebMaster untuk Pemula”, Jakarta: Mediakita.

Rahman, Su, 2013; “Cara Gampang Bikin CMS PHP Tanpa Ngoding”, Jakarta Selatan: Media Kita. 